\title{
Obraz czynności bioelektrycznej mózgu w autyźmie dziecięcym
}

\author{
Picture of brain bioelectrical activity in childhood autism
}

\author{
Joanna Michalska (D), Bogna Malendowicz-Major (iD) \\ Katedra i Klinika Neurologii Wieku Rozwojowego UM im. K. Marcinkowskiego w Poznaniu, Oddział Kliniczny Neurologii Dzieci i Młodzieży \\ DOI:10.20966/chn.2019.57.451
}

\section{STRESZCZENIE}

Zaburzenia ze spektrum autyzmu (ASD) stanowią częsty problem kliniczny. Aktualnie poza metodami psychologicznymi i psychiatrycznymi bazującymi na obserwacji zachowań dziecka nie istnieje żaden biomarker, który byłby patognomoniczny dla ASD. Wykonywane rutynowo badania elektroencefalograficzne i neuroobrazowe niewiele wnoszą do rozpoznania ASD i monitorowania jego przebiegu. Elektroencefalografia może być jednak narzędziem, które w przyszłości pomoże poznać procesy leżące u podłoża ASD.

Słowa kluczowe: zaburzenia ze spektrum autyzmu, elektroencefalografia, czynność bioelektryczna mózgu

\section{ABSTRACT}

Autism spectrum disorder (ASD) is a common clinical problem. Currently, apart from psychological and psychiatric methods based on observation of child's behavior, there is no biomarker that would be pathognomonic for ASD. Routine electroencephalographic and neuroimaging examinations do not contribute much to the diagnosis of ASD or monitoring its course. However, electroencephalography can be a tool that will help in the future to understand the processes underlying ASD.

Keywords: autism spectrum disorders, electroencephalography, brain bioelectrical activity
Zgodnie z klasyfikacją ICD-10 autyzm dziecięcy stanowi jeden $z$ wariantów całościowych zaburzeń rozwoju (PDD - pervasive developmental disorders). Do zaburzeń tych zalicza się także zespół Aspergera, zespół Retta oraz dziecięce zaburzenie dezintegracyjne. Klasyfikacja DSM5 określa natomiast całą grupę zaburzeń ze spektrum autyzmu (ASD - autism spectrum disorder) i nie wyszczególnia odrębnych jednostek chorobowych ze względu na ich nieostre granice i zmienność objawów w różnych okresach rozwoju dziecka. Wyróżnia natomiast zespół Retta jak odrębną jednostkę chorobową. Zgodnie z DSM5 o obecności zaburzeń ze spektrum autyzmu świadczą przetrwałe deficyty we wzajemnej komunikacji społecznej i interakcjach społecznych oraz ograniczone, powtarzalne wzorce zachowań, zainteresowań i aktywności. Zaburzenia ze spektrum autyzmu są heterogenną grupą zaburzeń neurorozwojowych, o których wystąpieniu decydują czynniki genetyczne i środowiskowe. Przypuszcza się, że wystąpienie objawów ASD jest związane z uszkodzeniem struktur anatomicznych i szlaków neurorozwojowych w okresie wewnątrzmacicznym i (lub) wczesnym postnatalnym [1].

Aktualnie poza metodami psychologicznymi i psychiatrycznymi bazującymi na obserwacji zachowań dziecka nie istnieje żadne badanie diagnostyczne, które umożliwiłoby rozpoznanie ASD. Nie dysponujemy żadnym patognomonicznym dla ASD biomarkerem potwierdzającym lub wykluczającym te schorzenia. Różni badacze próbowali określić zmiany w mózgowiu u dzieci z autyzmem za pomocą dostępnych badań diagnostycznych. Vargason i wsp. [2] przanalizowali różnego rodzaju biomarkery, które moga być związane z ASD. Autorzy próbowali wykazać obec- ność specyficznych dla ASD zmian w mózgu przy użyciu badań neuroorbrazowych - przy wykorzystaniu różnych technik badań strukturalnych jak i funkcjonalnych. Ponadto analizowali różne czynniki metaboliczne i genetyczne mogące mieć związek z ASD. Wskazali także na możliwość wykorzystania elektroencefalografii oraz magnetoencefalografii do oceny aktywności mózgu u dzieci z ASD. Nie znaleziono jednak takiego biomarkera, który byłby patognomoniczny dla ASD i konieczne jest kontynuowanie wielokierunkowych badań w tym zakresie.

Jednym z narzędzi do oceny pracy mózgu jakim dysponujemy jest elektroencefalografia (EEG) i niektórzy badacze próbowali wykorzystać tą metodę w celu wykazania zmian w czynności bioelektrycznej mózgu u dzieci z ASD. W swoich pracach Tuchmann [3,4] wykazał, że w grupie pacjentów z ASD często występują różnego rodzaju nieprawidłowości w zapisie EEG. Około 20\% pacjentów z ASD w podstawowym spoczynkowym zapisie EEG wykazuje aktywność padaczkową głównie w postaci zmian ogniskowych (iglice). Jeszcze więcej zaburzeń napadowych u dzieci z ASD wykazują badania EEG wykonywane podczas snu. W pracy Chez i wsp. [5] wykazali, że aż $61 \%$ pacjentów z ASD wykazuje aktywność padaczkową w zapisie EEG bez obecności napadów padaczkowych podczas wyładowań. W badaniu przeprowadzonym na grupie 1014 dzieci z autyzmem przez Yasuhara [6] stwierdzono, że aż u 85,5\% badanych występowała w EEG czynność napadowa, a 37\% pacjentów miało zdiagnozowaną padaczkę objawową. W grupie badanych dzieci czynność napadowa najczęściej rozwijała się z okolic czołowych. W opracowaniu Achkar \& Spence czytamy, że u pacjentów z ASD można znaleźć wszystkie rodzaje nieprawi- 
dłowości w czynności bioelektrycznej mózgu: zmiany ogniskowe, wieloogniskowe oraz uogólnione. Obserwuje się uogólnione i ogniskowe zwolnienia czynności bioelektrycznej mózgu a także nieprawidłowości w zapisie snu. W większości przypadków występują ogniskowe grafoelementy padaczkowe o różnej lokalizacji czołowej, skroniowej, centralnoskroniowej lub potylicznej [7]. Milovanovic i wsp. [8] przeanalizowali zapisy EEG oraz video-EEG wykonane w czuwaniu i we śnie w grupie 112 dzieci z rozpoznaniem autyzmu. Ponadto oceniono zdolności adaptacyjne tych dzieci w skali Vineland Adaptive Behavior Scale-II (VABS-II). Pacjenci zostali podzieleni na trzy grupy: pierwsza - z rozpoznaną padaczką, druga - z czynnością napadową w zapisie EEG bez obecności napadów padaczkowych oraz trzecia - bez padaczki oraz bez nieprawidłowości w zapisie EEG. Nie wykazano istotnych zależności pomiędzy stopniem zaawansowania autyzmu a obecnością padaczki i zmian napadowych w zapisie EEG. Zmiany w czynności EEG nie miały wpływu na rozwój mowy w badanej grupie dzieci. Zaobserwowano, że dzieci z autyzmem, u których nie występuje padaczka i mają prawidłowy zapis EEG osiągają lepsze wyniki w zakresie rozwoju funkcji motorycznych badanych skalą VABS-II niż dzieci z padaczką lub z nieprawidłową czynnością bioelektryczną mózgu. Wang i wsp. [9] przeprowadzili analizę zapisu spoczynkowego EEG w grupie pacjentów z ASD i porównali ją z grupą pacjentów z prawidłowym rozwojem psychoruchowym. Do oceny czynności podstawowej wykorzystali analizę spektralną. Dowiedli, że w grupie pacjentów z ASD występuje zwiększona aktywność w obrębie lewej półkuli mózgu. W pracy Saby i wsp. [10] autorzy oceniali grupę niemowląt i małych dzieci w różnych etapach rozwoju i poszukiwali dyskretnych zmian w zapisie EEG oraz próbowali powiązać je z funkcjonowaniem społecznym i emocjonalnym. W obszarze ich zainteresowań pojawiły się centralne rytmy mu oraz ich zmienność w zależności od aktywności niemowląt, asymetria w zapisie rejestrowanym z okolic czołowych i powiązanie jej z określonymi aktywnościami społecznymi i emocjonalnymi niemowląt. Istotne różnice pomiędzy funkcjonowaniem mózgu w grupach dzieci autystycznych i dzieci z prawidłowym rozwojem wykazano także wykonując analizę entropii EEG. Entropię badano czterema metodami: entropią próbki (SampEn), entropią rozmytą (FuzzyEn), entropią falkowa Renyi (RWE) i entropią premutacyjna Renyi (RPE). Badanie wykonano w grupie 43 dzieci autystycznych i 43 dzieci zdrowych uwzględniając wiek tych dzieci. Wykazano, że wiek zarówno w grupie dzieci autystycznych jaki i dzieci zdrowych wpływa na poziom entropii oraz, że różne rodzaje entropii wykazują istotne różnice w poszczególnych polach mózgu u pacjentów z prawidłowym rozwojem i z ASD [11]. Uważa się, że u podłoża zaburzeń autystycznych leżą niepra- widłowości w zakresie połączeń pomiędzy półkulami mózgu. Procesy te były badane za pomocą zaawansowanych technik elektroencefalograficznych - między innymi przy wykorzystaniu koherencji, która służy do badania współzależności w czynności poszczególnych struktur mózgu. W swojej pracy Duffy and Heidelise [12] wykazali, że stabilny wzór koherencji widmowej EEG odróżnia dzieci z autyzmem od dzieci bez ASD. Czynność bioelektryczna mózgu u pacjentów z ASD była także analizowana przy pomocy magnetoencefalografii (MEG). W pracy autorzy wykazali, że aby lepiej zrozumieć złożone interakcje między poszczególnymi regionami mózgu oraz charakter połączeń między nimi konieczne jest prowadzenie dalszych badań przy użyciu MEG [13].

Podsumowując, badanie EEG jest metodą, którą można wykorzystać w ocenie pracy mózgu u dzieci z autyzmem. Nie ma jednak typowych wzorców EEG, które byłyby jednoznaczne i swoiste dla autyzmu dziecięcego. Wykonanie badania EEG jest konieczne przy podejrzeniu padaczki $\mathrm{u}$ dzieci z ASD, nie wnosi natomiast istotnych informacji klinicznych przy braku napadów padaczkowych.

\section{PIŚMIENNICTWO}

[1] Słopień A. Wybrane zaburzenia neurorozwojowe [w:] Neurologia Wieku Rozwojowego. Steinborn B. [red.], PZWL, Warszawa 2017

[2] Vargason T., Grivas G., Hollowood J., et al.: Towards a Multivariate Biomarker-Based Diagnosis of Autism Spectrum Disorder: Review and Discussion of Recent Advancements. Seminars in Pediatric Neurology, Elselvier Article in press

[3] Tuchman R., Rapin I.: Epilepsy in autism. Lancet Neurol 2002; 1: 352-358.

[4] Tuchman RF., Rapin I.: Regression in pervasive developmental disorders: seizures and epileptiform electroencephalogram correlates. Pediatrics 1997; 99: 560-566.

[5] Chez MG., Chang M., Krasne V., et al.: Frequency of epileptiform EEG abnormalities in a sequential screening of autistic patients with no known clinical epilepsy from 1996 to 2005. Epilepsy Behav 2006; 8: 267-271.

[6] Yasuhara A.: Correlation between EEG abnormalities and symptoms of autism spectrum disorder (ASD) Brain Dev. 2010; Nov;32: 791-798.

[7] Achkar C., Spence S.: Clinical characteristics of children and young adults with co-occurring autism spectrum disorder and epilepsy. Epilepsy\&Behavior 2019; 92: 45-52.

[8] Milovanovic M., Radivojevic V., Radosavljev-Kircanski J., et al.: Epilepsy and interictal epileptiform activity in patients with autism spectrum disorders. Epilepsy\&Behavior 2015; 47: 183-190.

[9] Wang J., Barstein J., Ethridge L., et al.: Resting state EEG abnormalities in autism spectrum disorders. Journal of Neurodevelopmental Disorders 2013; 5: 24.

[10] Saby J., Marshall P.J.: The Utility of EEG Band Power Analysis in the Study of Infancy and Early Childhood Dev Neuropsychol. 2012; 37: 253273.

[11] Kang J., Chen H., Li X., et al.: EEG entropy analysis in autistic children. Journal of Clinical Neuroscience 2019; 62: 199-206.

[12] Duffy F., Heidelise A.:, A stable pattern of EEG spectral coherence distinguishes children with autism from neuro-typical controls - a large case control study. BMC Med. 2012 Jun 26;10: 64:

[13] O'Reilly C., Lewis J.D., Elsabbagh M.: Is functional brain connectivity atypical in autism? A systematic review of EEG and MEG studies. PLoS ONE 2017; 12(5): e0175870. https://doi.org/ 10.1371/journal.pone 